\title{
Comprehensive Supervision Model And Professional Competences Of Prospective School Counselors
}

\author{
Agus Taufiqa \\ ${ }^{a}$ Educational Psychology and Guidance. Faculty of Education. Universitas Pendidikan Indonesia \\ Bandung, West Java, Indonesia \\ Corresponding e-mail: afiq@upi.edu
}

\begin{abstract}
The purpose of the research was to develop the comprehensive supervision model which is effective to improve the professional competence of prospective school counselors in Counselor Education Program for Program of Bachelors Educating in Rural Areas. The Design-Based Research procedure was employed in this research. The research participant was 22 prospective school counselors, eight school counselors (site-supervisor), and six counselor educator (supervisor). The research held in the Department of Educational Psychology and Guidance, Faculty of Education, Universitas Pendidikan Indonesia. The results show that the comprehensive supervision model is effective to improve the professional competence of prospective schools counselors. The research implications of counselor education and supervision are also discussed in this article.
\end{abstract}

Keywords: comprehensive supervision model; professional school counselor competence; prospective school counselor

\section{INTRODUCTION}

An issue of the low professional competences of schools counselors in Indonesia, especially after regulation of the Ministry of National Education No.27 year 2008 on academic qualification standards and counselor competences and act No.14 year 2005 on Teachers and Lecturers, is getting stronger. Research results by [24] on professional performance of school counselors after the national certification program for teachers show that there is no significance difference of professional performance between teachers who have joined the program and those who have not.

In Indonesia, according to the regulation of teacher professional education (school counselors are included), prospective school counselors need to take two steps comprising academic education program and professional education program. Academic education is meant to develop their academic competences through the mastery of knowledge, theories, and concepts of education and counseling. Professional education, on the other hand, is meant to build competences needed in the field for the sake of effective supervision [25].

In the context of professional education of school counselors, internship supervision is a vital component [4] as a means of the development of professional identity (Herlihy, Gray, \& McCollum,
2002) and a contributive factor towards the whole experiences of the school counselors' professional education [12]. Internship supervision is crucial for the counselors' development [4]. The license standards and requirements by Council for Accreditation of Counseling and Related Education Program [10] emphasizes the importance of supervision to the development of students as professional counselors. In addition, American Counselor Association [1] also emphasizes the professional development and career supervision of counselors and also their obligation to regularly participate in continuous education related to topics and skills of counseling and supervision (standard of F.2.a). Hackney \& Cormer (2000), to this relation, agrees that development of having good supervision in internship gives a significant impact to the performance of prospective counselors. This is also in line with several empirical findings that supervision is a vital factor in developing the personal and professional competences of counselors ([4]; [8]; [23]; [9]; [18]; [23]), related to improving quality (Hackney, 2000; [38]; [41]), having feedback and evaluation of the performance [14], and having impacts on counseling knowledge and skills (Hawkins \& Shohet dalam Proctor, 2000).

In this context, the researcher is motivated to improve the quality of competences of prospective counselors through a strategic effort which is the 
improvement of internship supervision on PPGBK (Pendidikan Profesi Guru Bimbingan dan Konseling), professional education of school counselors in a program namely SM3T (Sarjana Mengajar di Daerah Terluar, Terdepan, dan Tertinggal), bachelors teaching in remote areas.

Even through there are several existing model of counseling supervision (Bernard \& Goodyear, 2008), there is no such consistent agreement among experts on a specific model in supervision of prospective school counselors. In this study, Integrative Development Model [39] and Discriminating Model [3] are the bases of model development for the supervision that is clinical, administrative, and integrated since those bases are considered comprehensive. Another model used in this study is a competence-based supervision model [13].

This study, particularly in relation to the comprehensive supervision model, tries to answer the following questions: (1) What type of internship supervision model that can hypothetically guarantee the academic competences of prospective school counselors? and (2) What are the effects of the implementation of Comprehensive Supervision Model towards the integration of competences of prospective school counselors?. Thus, the main purpose of the study is to create an internship supervision model that is empirically effective in integrating the competences of prospective school counselors so that the model can be the operational guidance for both supervisors and prospective school counselors in doing the internship supervision. Nevertheless, due to the limitations of the current study, there will merely be brief explanations, both verbal and visual, on the model without providing any manual of the model.

Finally, the development the comprehensive supervision model is expected to (1) fill the gap of necessary internship supervision models for prospective school counselors that have positive impacts towards the existing supervision models that are no longer relevant; and (2) provide some guidance that is scientifically proven to be effective.

\section{RESEARCH METHODS}

\subsection{Research Design}

This study uses Design-Based Research (DBR) which aims to guide an intervention plan or preparation. This method is used to test the effectiveness of an intervention effectively [2], and reflect the processes of planning, development, implementation, and revision of the intervention on education [26]. The whole processes of the research in this study go through three steps within two years. First step is planning which includes (1) pilot study to find out the existing condition of the internship supervision program especially after the paradigm shift of professional education of school counselors; and (2) literature study to acquire the most suitable internship supervision model to prepare competent prospective school counselors. Second step is the model development that covers (1) designing hypothetical internship supervision model; (2) validating the model by experts and practitioners; (3) revising the model; (4) implementing the model and observing its impacts on the reaching the required competences of prospective school counselors; (5) research evaluation; (6) finalizing the model; and (7) reporting and disseminating the model.

\subsection{Participants}

The participants involved in this study are 36 people consisting of 22 prospective school counselors (14 female and 6 male participants) and 14 supervisors consisting of six lecturer counselors (4 male and 2 male lecturers) as supervisors from the faculty, and eight school counselors ( 5 female and 3 male counselors) as site supervisors.

\subsection{Data Collection}

There are two types of quantitative data required in this study (1) descriptive data on opinions, feedback, and recommendation from counseling experts about the initial model of the proposed internship supervision model, and (2) documents such as results of oral and written tests, practicum tests, and also portfolio as the assessment items of the internship supervision. The first data are collected through focus group discussion with eight lecturer counselors (faculty supervisors) and six school counselors (site supervisors). This type of descriptive data are then analyzed by the three research members called consensual qualitative investigation [22]. This method highlights the importance of the researchers finding consensus on the systematic conclusions on statements spoken by the research participants. This is to actually answer the second research question. The other type of data, on the other hand, are collected through a series and tests related to the internship supervision needs and then analyzed to determine the grade point average of each prospective school counselors to decide whether they pass the national requirements or not. This is to answer research question number three. 


\subsection{Data Analysis}

The data analysis consists of coding domains, abstraction of core ideas in each domain, cross analysis, external audit, and stability checking. In coding domains, researchers make a list of domain codes based on interview protocol of literature study and transcript of the interview. After that, each result is included into each domain code to have the best results. In abstracting main ideas of each domain, researchers check and recheck the results of the interview transcript. In cross-analysis, researchers try to identify common and typical ideas of the main ideas of the respondents. In external audit, an expert of counseling is invited to study the process of data analysis and conclusion so the expert can give professional feedback regarding the analysis and conclusion. Finally, in the stability checking, researchers make sure the consistency of all research results in this study.

\section{FINDINGS AND DISCUSSION}

\subsection{Findings}

The results of the study show that the comprehensive supervision model is effective for the prospective school counselors to integrate the professional competences required. This is supported by the grade of all the prospective school counselors in this study who exceed the minimum grade requirement ( 75 out of 100 ). Their national grade point average is 82.6. And this, once again, exceeds the minimum requirement set by the ministry of higher education, science, and technology of Indonesia.

The visualization of this model is presented in Figure 1 and Table 1 . In the figure and table, there are explanations about how supervisors run the internship supervision program to be able to acquire the professional competences of the prospective school counselors. Below is a series of processes prospectve school counselors in Indonesia need to take in professional education.

a. Academic and administrative registration. This is to make sure that students (propective counselors) are officially registered.

b. Orientation of counselor professional education. This process is to make them understand the whole system, processes, and mechanism of the program.

c. Orientation of the schools. This is to introduce them all the things related to the school in which they do their practicum (internship).

d. Workshop on assessment. This is to prepare them for effective evaluation that is relevant to various needs of the school, the students, and the environment of their prospective practicum place.

e. Workshop on the program development. This is to enable them to make priorities, design comprehensive counseling programs, and set up effective schedules (including selecting appropriate media for each counseling program).

f. Simulation. The simulation is done in the laboratory so that they are able to design effective design and media of the counseling program they develop.

g. Implementation of the counseling program that consists of:

a) Type A group counseling. In this program, they (the prospective school counselors), need to a 45-minute session each week to discuss things related to personal, social, learning, and career development. They need to conduct 50 sessions of group counseling.

b) Type B group counseling. In this program, the prospective school counselors need to put more focus on each individual within the group talking about the same topics in type A. For this type of counseling, they have to conduct 100 sessions during the program.

c) Individual counseling. This is more likely to be a face to face counseling program. Discussing the aforementioned topics, the prospective school counselors need to conduct 200 sessions of this type of counseling.

d) Supporting activities. These activities have to be equal to 50 sessions of the counseling. Some of the activities are:

1). Consultation and collaboration with teachers and parents of their students;

2). Participation in such activities as extracurricular or any other regular after school activities.

h. Portfolio report. All the prospective school counselors need to eventually report all their counseling programs during the professional education in a form of portfolio as their academic responsibility.

i. Evaluation. After going through all rigorous processes of practicum program during the education, all the prospective school counselors need to take several tests contain oral test and online written test to assess their performance.

j. Peer evaluation. In addition to the test mentioned above, another requirement for the prospective school counselors to pass the education process is when their peers state positive feedback about them, especially 
related to their social behavior in the dormitory.

In general, all participants of the professional education for school counselors need to conduct 600 sessions of counseling program ( 1 session $=45-50$ minutes) that have to be finished in one year during their education. 400 sessions of them are all sessions of core competencies (counseling) and 200 of them are more likely to be managerial activities. Each participant of the program is supervised by a supervisor from the faculty and one supervisor from the school where they do their practicum (site supervisor). The whole supervision processes by those two supervisors are to make sure that each participant (1) follow all the procedure and mechanism of the professional education program; and (2) show integrated professional competences of school counselors.

\subsection{Discussion}

As discussed before, the results of the study show that comprehensive supervision model is effective to develop the professional competencies of prospective school counselors in a professional education program in SM-3T. This model is developed based on IDM and discriminating model. This actually support an assumption that the essence of supervision is professional intervention (Bernard and Goodyear, 1998). In another definition, supervision should focus on three aspects including administrative evaluative and clinical, and developmental supervision (Powell \& Brodsky, 2004). In the context of counseling, there are differences among clinical supervision, administrative supervision, and developmental supervision. Clinical supervision focuses on the counseling skill development and also the effectiveness of the supervised people. Administrative supervision emphasizes on aspects of administration and working procedure such as which documents to use, which rules to follow, etc. Developmental supervision, in the meantime, highlights the development of the counselors; how they become better in knowledge and skills, etc.

Another expert in counseling, Broder (1989) identifies that there are four models that are applicable in counseling. He also furthers explains that there is no best model for all situations. One model that is best implemented in one situation might not work in another situation. Those four models he proposes are (1) competency-based model, treatment-based model, developmental approaches, and integrated models.

Results of study also strengthen that competence-based model, discriminating model [4], and task-based model (Mead, 1990) focusing on skills and learning materials required by the supervisees are effective. The use of demonstration and various functions such as teaching, consultation, and counseling are proven to be flexible and relevant to the needs of the supervisees.

Supervision is also fundamental in the development and evaluation of (1) skills [6]; (2) prosperity; and (3) competences and effectiveness [40]. The main duties of clinical supervisors are to monitor the counseling activities, giving feedback through reflective dialogs teach and evaluate the effectiveness of supervisees. This research result affirms that the developmental supervision models focus on (1) counseling performance skills that cover verbal and non-verbal skills of responding, (2) counseling cognitive skills that include skills to conceptualizing theories into practices, (3) selfawareness which covers skills to understand that their own responses, opinion, motivation, and faith influence their counseling performance, and (4) professional behaviors which contain ethical and legal procedures in the counseling program (on site procedures).

To this relation, [43] states that supervisors rarely have trainings and learning exposure on how to conduct effective counseling program or psychotherapy. In the model implemented in this study, there are eight specific domains of clinical activities [39] including (1) intervention skill competence, (2) assessment techniques, (3) interpersonal assessment, (4) supervisee conceptualization, (5) individual differences, (6) theoretical orientation, (7) treatment planning and purposes, and (8) professional ethics.

[4] and Powell \& Brodsky (2004) argue that the quality of clinical supervision models are indicated by (1) rooting to individuals, either the style or approach of leadership; (2) accurate, clear, and consistent; (3) comprehensive with modern scientific proves; (4) operational and practical; (5) development-based; and (6) creating self-esteem of mastery and development to the supervised counselors and fulfilling the needs of the organization, supervisors, supervisees, and counselees.

Supervision is close related to an effort to enforce culture in a certain professional or organizational education system [37]; Border \& Bernard, 2009). It enables supervisors to see how close the behaviors of the prospective school counselors with the real implementation of standardized counseling that need certain competences. Having experiences of a good internship supervision program is significantly influential towards the performance of the counselors (Hill, Charless, \& Red, 1981). A study on 
internship supervision shows that there is positive correlation between supervised internship program and the needs of counselors' competences (Reising\&Daniels,1983; Wiley \&Ray, 1986).

Another literature shows that there are more benefits of supervision towards basic skills of counseling rather than advanced skills of counseling [39]. In addition, the purpose of clinical supervision is to help prospective school counselors develop their professional competences in giving counseling and protecting the well-being of the counselees (Borders \& Brown, 2005). Another empirical study finds that unsupervised supervision program does not help the prospective counselors to develop their competences [44]. In supervision, supervisors function as evaluators of the prospective school counselors' professional competence development (Bernard \& Goodyear, 2009).

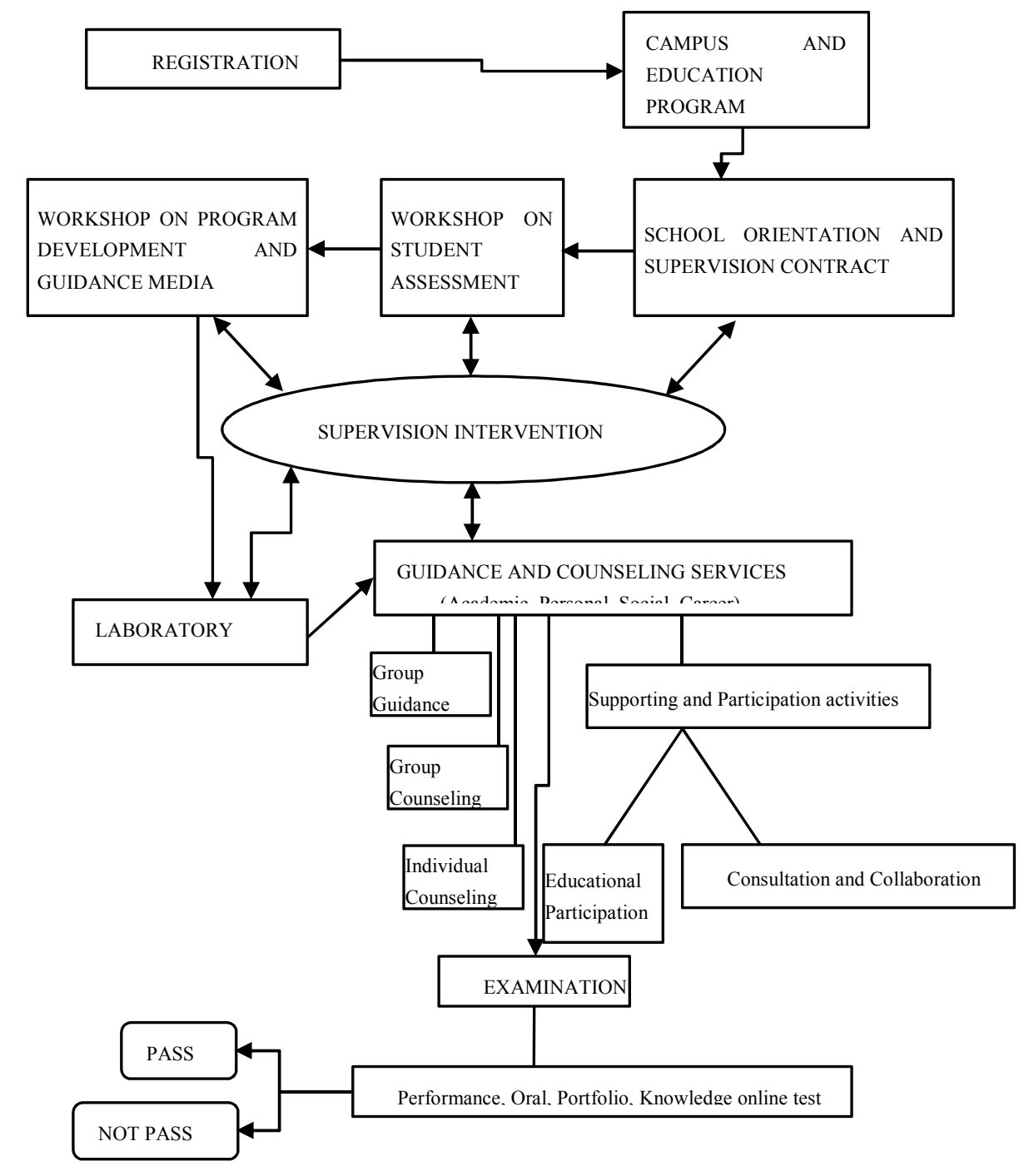

Fig. 1. Parts of Internship Supervision of Professional Education Program for Prospective School Counselors

Explanation:

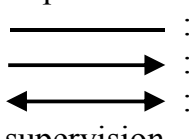

Explaining parts

Explaining processes

Explaining intervention related to
[36] finds that supervisor is an important factor in the development of supervisees. Furthermore, [32] state that the relationship between supervisors and supervisees affect the relationship of supervisees with the counselees. To align with this, [27] proves that support from the supervisors, in addition to a 
well-organized supervision program, is influential to the supervisees' self-efficacy. The current study also supports the statement that professional competences can be mastered through a well-established supervised [15]. In other words, the quality of relationship between supervisors and supervisees will affect the development of professional competences and self-efficacy of the supervisees.

\section{CONCLUSION, IMPLICATION, AND RECOMMENDATION}

\subsection{Conclusion}

To conclude, there are two major findings of the study: (1) Comprehensive Supervision Model in professional education program for prospective school counselors, as long as it is integrated, is effective; and (2) The model is an empirical evidence that affirms the success of IDM, discriminant model, and competence-based supervision model.

\subsection{Implication and Recommendation}

Supervision is a vital, strategic, and essential part in developing and guaranteeing the professional competences of prospective school counselors; however, lack of supervision trainings are becoming a serious issue that needs more attention from people involving in this, especially AKBIN, Asosiasi Bimbingan dan Konseling Indonesia, (Indonesian Counseling Association) and further researchers. There is an urgency to interpret concepts of wellestablished internship supervision program so that site supervisors, school, and prospective school counselors will have detailed and explicit instructions that are in the same frequency with the comprehensive theories on counseling.

In relation to this, it is recommended that (1) there needs to be a training for supervisors and site supervisors based on comprehensive supervision model, (2) experts, policy makers, and researchers need to be involved in the internship supervision program, (3) there has to be standardized competences of supervisors, site supervisors, and internship place, and (4) the roles of supervisors and site supervisors need further discussion.

Supervisors from universities usually have plenty theories and concepts and ideal counseling yet few experiences in the real counseling program. On the other hand, site supervisors have more experiences in real-life counseling programs but lack in theoretical knowledge on counseling. Thus, these two parties need to be collaborated well to create a good combination of theoretical and practical framework on counseling.

\section{REFERENCES}

[1] American Counseling Association. ACA code of ethics. Alexandria, VA: Author. 2014.

[2] Barab, S., \& Squire, K. Design-based research: Putting a stake in the ground. Journal of the Learning Sciences, 2004. 13, 1-14.

[3] Bernard, J. M. The discrimination model.In C. E. Watkins.Handbook of psychotherapy supervision (pp. 310-327). New York: Wiley. 1997.

[4] Bernard, J. M., \& Goodyear, R. K.Fundamentals of clinical supervision $\left(5^{\text {th }}\right.$ Edition).Upper Saddle River, New Jersey: Pearson, 2014.

[5] Borders, L. D. Credentialing supervisors: A commitment to professionalism. Illinois Association forCounseling and Development Quarterly, 1989b, 112, 33-42.

[6] Borders, L. D. Learning to think like a supervisor.The Clinical Supervisor, 10, 1993, 135-148. doi:10.1300/J001v10n02_09

[7] Borders, L.D., Bernard, J. M., Dye, H. A., Fong, M.L.,Henderson, P.,\& Nance, D. W. Curriculum guide for training counseling supervisors: Rationale, development and implementation. Counselor Education and Supervision, 1991, 31, 58-80.

[8] Caroll, M. Effective supervision for helping professions ( $2^{\text {nd }}$ Edition). London: Sage Publication Inc, 2014.

[9] Corey, G., Hayes, R.H., Moulton, P., \& Muratori, M. Clinical supervision on the helping professions: A practical guide $\left(2^{\text {nd }}\right.$ Edition). New York: Willey, 2014.

[10]Council for Accreditation of Counseling and Related Education Programs. 2016 CACREP standards. Alexandria, VA: Author, 2015.

[11]Direktorat Jenderal Peningkatan Mutu Pendidik dan Tenaga Kependidikan Republik Indonesia. Penataan Bimbingan dan Konseling pada Jalur Pendidikan Formal. Jakarta: Depdiknas RI, 2007.

[12]Derrick, E.C. Exploring supervisor and supervisee experiences of triadic supervision (doctoral dissertation).Retrieved from ProQuest, 2010.

[13]Falender, C.A., \& Shafranske, E.P. Clinical supervision: A competency-based approach. Washington, DC : American Psychological Association, 2004. 
[14]Frick, M.H., \& Glossof, H.L. Becoming a supervisor: qualitative findings on self-efficacy beliefs, of doctoral student supervisor-intraining.The Professional Counselor, 2014, 4 (1), 35-48.

[15] Frymier, A. B., \& Houser, M. L. The teacherstudent relationship as an interpersonal relationship.Communication Education, 2000, 49, 207-219. doi: $10.1080 / 03634520009379209$

[16] Goldberg, R., Dixon, A., \& Wolf, C.P. Facilitating effective triadic counseling supervision: An adapted model for an underutilized supervision approach.The Clinical Supervisor, 2012, 31, 42-60.

[17] Hackney, H., \& Cormier, S. The professional counselor: A cross guide to helping. New Jersey: Pearson, 2009.

[18] Hawkins, P. Supervision in the helping professions: An individual, group, and organizational approach (2 $2^{\text {nd }}$ Edition). Buckingham Philadelphia: Open University Press, 2000.

[19]Hein, S.F., \& Lawson, G. A qualitative examination of supervisor's experiences of the process of triadic supervision.The Clinical Supervisor, 2009, 28, 91-108.

[20]Hein, S.F., Lawson, G., \& Rodgriguez, C.P. Supervisee incompatibility and its influence on triadic supervision: An examination of doctoral student supervisor's perspectives. Counselor Education and Supervision, 2011, 50, 422-436.

[21] Hein, S.F., Lawson, G., \& Rodgriguez, C.P. Supervisee incompatibility and influence on supervisee and supervisor outcomes in triadic supervision. The Clinical Supervisor,2013, 33, 260-279.

[22]Hill, Knox, Thompson, William, Hess \& Ladany, Consensual Qualitative Research: An Update. Journal of Counseling Psychology, \%2(2), 2005, 196.

[23] Holloway, E., \& Caroll, M. Training counseling supervisors: Strategies, methods, and techniques. London: Sage Publication, 1999.

[24]Kania,D.Kinerja ProfesionalGuru BK Pasca Program Sertifikasi Guru.Tesis di. Universitas Pendidikan Indonesia, Bandung: tidak diterbitkan,2011.

[25] Kartadinata, S. Menguak Tabir bimbingan dan konseling sebagai upaya pedagogis. Bandung: UPI Press, 2014.

[26] Kelly, A. Design research in education: Yes, but is it meth- odological/ Journal of the
Learning Sciences, 2004, 13, 115-128. doi:10.1207/s15327809jls1301_6

[27] Larson, L. M. The social cognitive model of counselor training.The Counseling Psychologist, 1998, 26, 219-273.

[28] Lawson, G., Hein, S.F., \& Stuart, C.L. A qualitative investigation of supervisee's experiences of triadic supervision. Journal of Counseling and Development, 2009, 87, 449457.

[29]Lawson, G., Hein, S.F., \& Stuart, C.L. Supervisors' experinces of the contributions of the second supervision in triadic supervision: A qualitative investigation. Journal for Specialists in Group Work, 2010, 35 (1), 69-91.

[30]Lenz, A. S., Sangganjanavanich, V. F., Balkin, R. S., Oliver, M., \& Smith, R. L. Wellness model of super-vision: A comparative analysis. Counselor Education and Supervision, 2012, 51,207-221.doi:10.1002/j.15566978.2012.00015.x

[31]Lonn, M.R. In search of best practice: A review of triadic supervision literature. VISTAS 2014, 2014, 1-12.

[32] Patton, M. J., \& Kivlighan, D. M. Relevance of the supervisory alliance to the counseling alliance and to treatment adherence in counselor training.Journal of Counseling Psychology, 1997, 44, 108-115.

[33] Peraturan Menteri Pendidikan Nasional No. 27 Tahun 2008 tentang Standar Kualifikasi Akademik dan Kompetensi Konselor.

[34]Prieto,L.R. Groupsupervision: Stillwidely practiced but poorly understood. CounselorEducation and Supervision, 1996, 35, 295- 307.

[35] Proctor, B. Group supervision: A guide to creative practice. London: Sage Publication, 2000.

[36] Ramos-Sanchez, L., Esnil, E., Goodwin, A., Riggs, S., Touster, L. O., Wright, L. K., Ratanasiripong, P., \& Rodolfa, E. Negative supervisory events: Effects on supervision satisfaction and supervisory alliance. Professional Psychology, Research and Practice, 2002, 33, 197-203.

[37] Satori, J. "Pengembangan sistemjaminan mutu dalam praktek supervisi sekolah”.Makalah.Bandung:tidak diterbitkan, 2004.

[38] Shipton, G. (Ed). Supervision of psychotherapy and counseling. Buckingham Philadelphia: Open University Press, 2000. 
[39] Stoltenberg,C.D.,McNeil,B.,\&Delworth,U. IDMsupervision:Anintegrateddevelopmentalmo delforsupervisingcounselorsandtherapists.Josse y-BassPublishers,SanFrancisco,CA, 1998.

[40] Swank, J. M., Lambie, G. W., \& Witta, E. L. An exploratory investigation of the Counseling Competen-cies Scale: A measure of counseling skills, dispositions, and behaviors. Counselor Education and Super-vision, 2012, 51, 189-206. doi:10.1002/j.1556-6978.2012.00014.x

[41] Taufiq, A., Ahmad, S.N., \& Saripah, I. Supervisi kinerja guru bimbingan dan konseling/konselor (bahan ajar).Bandung: Jurusan PPB FIP UPI (tidak diterbitkan), 2010.

[42] Undang-Undang Republik Indonesia Nomor 14 tahun 2005 tentang Guru dan Dosen

[43] Watkins, C.E., Jr. Supervision process seen asa process ofexperiential learning.The Clinical Supervisor, 1997, 16 1, 145-161.

[44] Wiley, M., \& Ray, P. Counseling supervision by developmental level.Journal of Counseling Psychology, 1986, 33, 439-445. 